\title{
Comparative Study of Quality and Nutritive Parameters of Insect Infested Bengal Gram under Vacuum and Modified Atmosphere Storage in Laminated LDPE Bags
}

\author{
Nidhi Khanna*, Priti Jain and C.K. Teckchandani \\ College of Agricultural Engineering, JNKVV, Jabalpur (M.P.), India \\ *Corresponding author
}

\begin{tabular}{|c|c|}
\hline \multicolumn{2}{|r|}{ A B S T R A C T } \\
\hline & \multirow{6}{*}{$\begin{array}{l}\text { The effect of vacuum and modified atmospheric storage on quality parameters of insect } \\
\text { infested bengal gram was studied. The bengal gram samples were packed with five insects } \\
\text { of Callosobruchus chinensis under vacuum, modified atmosphere and ambient storage } \\
\text { conditions for } 120 \text { days, in laminated LDPE bags. To find the effect of vacuum and } \\
\text { nitrogen gas as modified storage on the parameters viz., moisture content, germination } \\
\text { percentage, change in weight, rehydration capacity and protein content of bengal gram } \\
\text { were analysed on every } 30 \text { days interval for } 120 \text { days. At each interval of storage, the } \\
\text { significant differences were observed in increase in moisture content, rehydration capacity } \\
\text { and change in weight and decrease in protein content and germination percentage in } \\
\text { respective storage conditions. The observation found that increase in moisture content on } \\
\text { wet basis ranged from } 8.2 \% \text { to } 8.46 \% \text {, } 8.86 \% \text { and } 9.86 \% \text {, rehydration capacity has } \\
\text { increased from } 0.210 \text { to } 0.235,0.243 \text { and } 0.250 \mathrm{~g} / \mathrm{g} \text {, change in weight from } 0.0 \mathrm{~g} / \mathrm{g} \text { to } 0.333 \text {, } \\
1.767 \text { and } 2.5 \mathrm{~g} / \mathrm{g} \text { and protein content has decreased from } 19.650 \% \text { to } 18.063 \text {, } 16.338 \text { and } \\
16.063 \% \text { and germination percentage has decreased from } 100 \% \text { to } 99.333 \% \text {, } 95 \% \text {, } \\
84.667 \% \text { in vacuum, modified storage and ambient condition respectively. The results } \\
\text { showed that vacuum is the best storage technique for bengal gram storage. }\end{array}$} \\
\hline & \\
\hline $\begin{array}{l}\text { Bengal gram, } \\
\text { Modified atmospheric } \\
\text { storage, Vacuum, } \\
\text { Insect infestation, } \\
\text { Quality parameters. }\end{array}$ & \\
\hline Article Info & \\
\hline $\begin{array}{l}\text { Accepted: } \\
28 \text { October } 2017 \\
\text { Available Online: } \\
10 \text { December } 2017\end{array}$ & \\
\hline & \\
\hline
\end{tabular}

\section{Introduction}

Pulses are rich source of protein (lysine), low fat, high carbohydrates, fiber, low sulfur containing amino acids, micronutrients and vitamins, which help to get rid of protein malnutrition among vegetarian people especially children and nursing mothers. Bengal gram (Cicer aritinum L.) is the third most important pulse crop, produced in the world after dry bean and peas (http://www.aicrpchickpea.res.in). Bengal gram is widely used as protein rich supplement to achieve better health in developing countries. Though, pulses have high protein content, suffer very high insect infestation and thus undergo heavy losses during storage.

During storage, some chemical changes occur in pulses and the result is significant change in quality losses due to external living organisms such as insects, rodents and microorganisms, discoloration, darkening due to oxidation, broken/cracked/split/peeled seeds, sprouting, odour, heat damage, etc. under natural conditions. Such deterioration results from interaction among physical, 
chemical, physiological and biological variables. It's stability as well as viability should be preserved by high-quality scientific storage methods. Scientific storage of pulses viz., hermetic storage, vacuum and modified atmosphere storage, mix storage, fumigation for in-situ treatment of stored materials and on structure with varying materials considerably important to check the deterioration, protects the quality of grain and help to stabilize the economy/ prices. It helps to supply of grain over time. To provide safe grains storage continuous research is going on at different research institution in the country.

In modified atmosphere storage, disinfestations of stored seeds using the alteration of the natural storage gases such as carbon dioxide, oxygen and nitrogen to create the lethal atmosphere to pests. It includes neither the alteration of the storage atmosphere by addition of toxic gases such as phosphine or methyl bromide nor atmospheric water content (Vasudevan et al., 2014). Studies in the 1860s on modifying atmospheres by adding N2 or "burned air" to grain storages were also reported by Sigaut (1980).

In Vacuum packaging, the product to be packed is placed under low atmospheric or negative pressure by drawing out the air from the pack prior to the final sealing to obtain insect kill within reasonable periods, it gives the significant effect on insect mortality (Navarro, 2006).

This increases storage or shelf life by inhibiting the growth of microorganisms and improves hygiene by reducing the danger of cross contamination, Meena et al., (2017). Sanjeev et al., (2006) and Meena et al., (2017) noted that vacuum packaging and gas flushing techniques are used for the purpose to extend the shelf life and prevention of food spoilage by oxidation.
Hence, the objectives of this study were to compare the effect of vacuum and modified atmosphere storage on nutritive value (protein) and quality parameters of sample of bengal gram.

\section{Materials and Methods}

The samples were procured from local market of Jabalpur, Madhya Pradesh. Each sample was stored for 120 days to evaluate the parameters viz., percent moisture content, germination percentage, rehydration capacity, percent protein content and change in weight at the regular interval of 30 days. The stored material was packed in laminated LDPE bags under vacuum and modified atmosphere packaging through purging of nitrogen gas along with five insects named Callosobruchus chinensis (Modgil et al., 1997; Chandel et al., 2015). These were also compared with ambient condition. To create vacuum inside the laminated LDPE bags, vacuum sealing machine was used. For modified storage, samples were kept first in vacuum condition and then nitrogen gas was released in the bags from liquid nitrogen gas cylinder through a special valve and pipe system. Consequently, bags were sealed by thermal sealer.

\section{Quality and nutritive parameters of bengal gram}

\section{Moisture content}

Moisture content of bengal gram was determined by indirect method i.e. using Universal Moisture Meter (Chandel, 2015).

\section{Seed germination}

The seeds were germinated by laboratory Seed Germinator. Fifty seeds were placed in wet towel paper. The spacing between seed to seed was kept five times the width of seed. Then the wetted paper was properly folded 
and one side was kept open for growth of seedlings.

Then this rolled paper was covered with butter paper for retaining proper humidity inside the towel paper. It was then placed in Seed Germinator at $25 \pm 1^{\circ} \mathrm{C}$ and close to saturation point. After 12 days the rolled paper were unfolded and germinated seeds were counted and germination percentage was found by following formula-

$$
\text { Germination } \%=\frac{\text { Number of germinated seed X } 100}{\text { Number of seeds kept for germination }}
$$

\section{Rehydration capacity}

$20 \mathrm{~g}$ samples were taken and steeped in water for $12 \mathrm{hr}$. at ambient temperature. Grain were removed and placed on filter paper to remove free surface water, then weighed. Similar method was adopted by Shimelis (2006) and Oluwatosin et al., (2016). Rehydration capacity was determined by following formula-

Rehydration capacity $=\frac{\text { Wright of soaked grain-Wright of unsoaked grain }}{\text { Wright of Sangle }}$

\section{Protein percentage}

Protein content of samples was determined by using Micro-kjeldahl Digestion and Distillation Procedure as given by AOAC (1965). Protein percentage was found by following formula-

protein $\%=\frac{\text { Normality of H2S04 X Titrated valueX } 14 \text { X } 6.25 \text { X100 }}{\text { Weight of Sample X } 1000}$

\section{Change in weight}

Change in weight was determined for stored samples under different storage conditions at a particular storage period using electronic weighing balance (Mekali Jayashree et al., 2013).

\section{Results and Discussion}

Effect of storage period at different storage conditions on moisture content of bengal gram

The moisture content of stored bengal gram increased with an increase in storage period for vacuum, modified atmosphere and ambient condition. The minimum increment in moisture content of $8.46 \%$ was found in vacuum followed by modified atmosphere of $8.86 \%$ and ambient condition of $9.86 \%$ respectively (Table 1 ). This is due to insect's metabolism which released heat and moisture. It also may be due to temperature and moisture gradients within stored products under ambient storage conditions. Therefore moisture increment had found minimum in vacuum storage followed by modified storage and ambient condition. The result showed maximum increment in moisture content in ambient conditions.

\section{Effect of storage period at different storage conditions on germination capacity of bengal gram}

The result showed that germination percentage of bengal gram stored in laminated LDPE bags decreased with an increase in storage time for vacuum, modified atmosphere and ambient condition. At the end of storage period i.e. 120 days, the best result was found in vacuum i.e. $99.333 \%$, followed by modified atmosphere of $95 \%$ and ambient condition of $84.667 \%$ respectively (Table 2). This may be due to respiration by grain as well as insects, mites and microorganisms during storage under ambient conditions and the result in loss of germination ability (http://www1.agric.gov.ab.ca/\$department/de ptdocs.nsf/all/crop1204) and (Meena et al., 2017). The same trend was also found by Roberts et al., (1968a) in peas. 
Effect of storage period at different storage conditions on rehydration capacity of bengal gram

The rehydration capacity of bengal gram stored in laminated LDPE bags increased with an increase of storage time for vacuum, modified atmosphere and ambient condition.
The rehydration capacity increased from $0.210 \mathrm{~g} / \mathrm{g}$ to $0.235 \mathrm{~g} / \mathrm{g}$ in vacuum followed by modified atmosphere of $0.243 \mathrm{~g} / \mathrm{g}$ and ambient condition of $0.250 \mathrm{~g} / \mathrm{g}$ respectively (Table 3 ). Similar trend also was found by Oluwatosin $e t$ al., (2016) for Moringa oleifera kernels and by Deepa et al., (2013) for stored chili seeds under vacuum.

Table.1 Effect of storage period on moisture content (\%) of stored bengal gram under different storage condition in laminated LDPE

\begin{tabular}{|l|l|l|l|}
\hline \multirow{2}{*}{$\begin{array}{l}\text { Storage period } \\
\text { (days) }\end{array}$} & \multicolumn{3}{|l|}{ Moisture content $(\%$, wb) at different storage conditions } \\
\cline { 2 - 4 } & Vacuum & $\mathrm{N}_{2}$ purged storage & Ambient condition \\
\hline 0 & 8.2 & 8.2 & 8.2 \\
\hline 30 & 8.3 & 8.6 & 8.9 \\
\hline 60 & 8.4 & 8.73 & 9.1 \\
\hline 90 & 8.46 & 8.76 & 9.58 \\
\hline 120 & 8.46 & 8.86 & 9.86 \\
\hline
\end{tabular}

Table.2 Effect of storage period on germination (\%) of stored bengal gram under different storage condition in laminated LDPE

\begin{tabular}{|l|l|l|l|}
\hline \multirow{2}{*}{$\begin{array}{l}\text { Storage } \\
\text { (days) }\end{array}$} & \multicolumn{3}{|c|}{ Geriod } \\
\cline { 2 - 4 } & Vacuum & $\mathrm{N}_{2}$ purged storage & Ambient condition \\
\hline 0 & 100 & 100 & 100 \\
\hline 30 & 100 & 97.667 & 94.333 \\
\hline 60 & 99.333 & 97 & 92 \\
\hline 90 & 99.333 & 95.333 & 87.333 \\
\hline 120 & 99.333 & 95 & 84.667 \\
\hline
\end{tabular}

Table.3 Effect of storage period on rehydration capacity $(\mathrm{g} / \mathrm{g}$ ) of stored bengal gram under different storage condition in laminated LDPE

\begin{tabular}{|l|l|l|l|}
\hline \multirow{2}{*}{$\begin{array}{l}\text { Storage } \\
\text { (days) }\end{array}$} & \multicolumn{3}{|c|}{ Rehiod } \\
\cline { 2 - 4 } & Vacuum & $\mathrm{N}_{2}$ purged storage & Ambient condition \\
\hline 0 & 0.210 & 0.210 & 0.210 \\
\hline 30 & 0.237 & 0.240 & 0.227 \\
\hline 60 & 0.228 & 0.245 & 0.237 \\
\hline 90 & 0.227 & 0.243 & 0.233 \\
\hline 120 & 0.235 & 0.243 & 0.250 \\
\hline
\end{tabular}


Table.4 Effect of storage period on protein content (\%) of stored bengal gram under different storage condition in laminated LDPE

\begin{tabular}{|l|l|l|l|}
\hline \multirow{2}{*}{ Storage period (days) } & \multicolumn{3}{|c|}{ Protein content (\%) at different storage conditions } \\
\cline { 2 - 4 } & Vacuum & $\mathrm{N}_{2}$ purged storage & Ambient condition \\
\hline 0 & 19.650 & 19.650 & 19.650 \\
\hline 30 & 18.925 & 17.925 & 17.063 \\
\hline 60 & 18.925 & 17.363 & 17.006 \\
\hline 90 & 18.338 & 17.063 & 16.625 \\
\hline 120 & 18.063 & 16.338 & 16.063 \\
\hline
\end{tabular}

Table.5 Effect of storage period on change in weight $(\mathrm{g})$ of stored bengal gram under different storage condition in laminated LDPE

\begin{tabular}{|l|c|c|c|}
\hline \multirow{2}{*}{ Storage period (days) } & \multicolumn{3}{|c|}{ Change in weight $(\mathrm{g}$ ) at different storage conditions } \\
\cline { 2 - 4 } & Vacuum & $\mathrm{N}_{2}$ purged storage & Ambient condition \\
\hline 0 & 0 & 0 & 0 \\
\hline 30 & 0 & 0.033 & 0.4 \\
\hline 60 & 0.067 & 0.3 & 0.833 \\
\hline 90 & 0.233 & 1.067 & 2.167 \\
\hline 120 & 0.333 & 1.767 & 2.5 \\
\hline
\end{tabular}

Effect of storage period at different storage conditions on protein percentage of bengal gram

With an increase in storage period, the protein percentage decreased for stored bengal gram under different storage condition. The maximum protein percentage of $18.063 \%$ was found in vacuum followed by modified atmosphere of $16.338 \%$ and ambient condition of $16.063 \%$ respectively (Table 4). It could be due to property of protein chains, which form loose mesh with increase in moisture content, when sample stored at room temperature in control conditions and under vacuum and modified atmosphere storage, it was found in decreased state. This trend was also found by Deepa et al., (2013) for chili seeds stored under vacuum.

Effect of storage period at different storage conditions on change in weight of bengal gram

The change in weight of stored bengal gram increased with storage time for vacuum, modified atmosphere and ambient condition. The minimum change in weight of $0.333 \mathrm{~g}$ was found in vacuum followed by modified atmosphere of $1.767 \mathrm{~g}$ and ambient condition of $2.5 \mathrm{~g}$ respectively (Table 5). Under ambient conditions the heating occurs within stored grains due to respiration of grain as well as insects and microorganism, which may be responsible for loss in weight (http://www1.agric.gov.ab.ca/\$department/deptdo cs.nsf/all/crop1204).Vacuum packaging inhibit the dehydration and weight loss in the stored product. Same trend was also found by Mekali Jayashree, (2013) at different concentration of $\mathrm{CO}_{2}$ for sorghum seeds and Divya et al., (2016) for horsegram stored under $\mathrm{CO}_{2}$ rich atmosphere.

The work were carried out for stored bengal gram in laminated LDPE bags under different storage conditions i.e. vacuum, modified atmosphere storage and ambient conditions for 120 days. It was found that increase in moisture content, rehydration capacity and change in weight with storage period had minimum in vacuum in comparison to modified atmosphere and ambient conditions. The minimum loss in protein content and germination percentage were found under vacuum condition than others. Therefore the storage of bengal gram under vacuum condition had significantly effective followed by modified atmosphere and ambient conditions.

\section{References}

AOAC 1965. Official methods of analysis, $10^{\text {th }}$ edn, Association of Official Agricultural Chemist. p 657. Washington. 
Chandel B.S. and Bhadauria D.S. 2015. Assessment of resistance to the attack of pulse beetle, Callosobruchus chenensis (Fabricius) in chickpea genotypes on the basis of various physical parameters during storage, $\mathbf{J}$ Entomology and Zoology studies. 3(2): 160-165

Deepa G.T., Mahadev B. Chetti, Mahadev C. Khetagounder and Gopal M. Adavirao. 2013. Influence of vacuum packaging on seed quality and mineral contents in chilli (Capsicum annuum L.). J Food Sci Technol. 50(1): 153-158

Divya P., Kanaka K. Durga, Sunil N., Rajasri M, Keshavulu K. and Udayababu P. 2016. Modified atmosphere storage technique for the management of pulse beetle, Callosobruchus chinensis in Horse gram. Legume Research. 39 (3) 2016: 474-478.

http://www.aicrpchickpea. res.in/

http://www1.agric.gov.ab.ca/\$department/deptdoc s.nsf/all/crop1204

Meena M.K., Chetti M.B., Nawalagatti C.M. and M. Chandra Naik. 2017. Vacuum Packaging Technology: a Novel Approach for extending the Storability and Quality of Agriculture Produce, Advances in Plants and Agriculture Research. 7(1): 00242

Mekali Jayashree, Naganagoud, A., Sreenivas, A. G., Somasekhar and Udaykumar Nidoni. 2013. Management of Sitophilus oryzae (L.) (Coleoptera: Curculionidae) under modified atmospheric condition on stored sorghum. Annals of Biological Research. Scholar's Research Library. 4(7):185-192. ISSN 0976-1233. CODEN (USA)

Modgil R. and Mehta U. 1997. Effect of infestation (Callosobruchus Chenensis L.) of chichpeas (Bengal gram) on biological utilization of proteins. Aug: 41(4): 236-8. Nehrung, NCBI

Navarro S. 2006. Modified atmospheres for the control of stored-product insects and mites. In Heaps JW (Ed): Insect Management for Food Storage and Processing. $2^{\text {nd }} E d n$. 105-146. AACC International, St. Paul, MN

Oluwatosin J. Oginni, Babatunde S. Ogunsina, Gbenga A. Olatunde, Kehinde F. Jaiyeoba. 2016. Influence of soaking and cooking techniques on Physical and Hydration Properties of Moringa oleifera Kernel. American journal of Food Science and Technology. Vol 4 (6) : 168-172

Roberts E. H. and Abdalla, F. H. 1968a. The influence of temperature, moisture and Oxygen on period of seed viability in barley, boardbeans and peas. Annuals of Botony. (N.S.) 32:97-117

Sanjeev K, Ramesh M.N. 2006. Low oxygen and inert gas processing of foods. Crit Rev Food Sci Nutr 46(5): 423-451

Shimelis Admassu Emire. 2006. Effects of Mineral Composition on Cooking Quality and Relationship Between Cooking and Physicochemical Properties of Ethiopian Bean (Phaseolus vulgaris L.) Varieties. Eth. Journal of Science and technology, 4 (1): $1-22$.

Sigaut, F. 1980. Significance of underground storage in traditional systems of grain production. In: Proc. Int. Symp. on Controlled Atmosphere Storage of Grains. J. Shejbal, Ed. Elsevier, Amsterdam. pp. 3-13.

Vasudevan S.N., Shakuntala N.M., Teli Shreshail, Goud Shanker, Gowda Basave and Ravi, 2014. Studies on Effect of Modified Atmospheric Storage Condition on Storability of Groundnut (Arachis hypogaea L.) Seed Kernels. International Journal of Research Studies in Biosciences (IJRSB), 2(2): 25-36

\section{How to cite this article:}

Nidhi Khanna, Priti Jain and Teckchandani, C.K. 2017. Comparative Study of Quality and Nutritive Parameters of Insect Infested Bengal Gram under Vacuum and Modified Atmosphere Storage in Laminated LDPE Bags. Int.J.Curr.Microbiol.App.Sci. 6(12): 4303-4308.

doi: https://doi.org/10.20546/ijcmas.2017.612.494 